\title{
A Short Integrated Presentation of Valuation, Profitability and Growth Analysis
}

\author{
Pettersson, Kim; Sørensen, Ole
}

\author{
Document Version \\ Accepted author manuscript \\ Published in: \\ International Journal of Accounting and Finance
}

DOI:

10.1504/IJAF.2016.076557

Publication date:

2016

License

Unspecified

Citation for published version (APA):

Pettersson, K., \& Sørensen, O. (2016). A Short Integrated Presentation of Valuation, Profitability and Growth Analysis. International Journal of Accounting and Finance, 6(1), 43-61.

https://doi.org/10.1504/IJAF.2016.076557

Link to publication in CBS Research Portal

\section{General rights}

Copyright and moral rights for the publications made accessible in the public portal are retained by the authors and/or other copyright owners and it is a condition of accessing publications that users recognise and abide by the legal requirements associated with these rights.

\section{Take down policy}

If you believe that this document breaches copyright please contact us (research.lib@cbs.dk) providing details, and we will remove access to the work immediately and investigate your claim.

Download date: 26. Apr. 2023

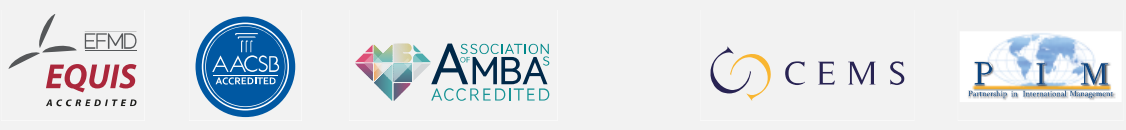




\section{A Short Integrated Presentation of Valuation, Profitability and Growth Analysis}

\section{Kim Pettersson and Ole Sorensen}

Journal article (Postprint version)

Cite: A Short Integrated Presentation of Valuation, Profitability and Growth Analysis. / Pettersson, Kim; Sørensen, Ole. In: International Journal of Accounting and Finance, Vol. 6, No. 1, 2016, p. 43-61.

DOI: http://dx.doi.org/10.1504/IJAF.2016.076557

Uploaded to Research@CBS: June २०16 


\title{
A short integrated presentation of valuation, profitability and growth analysis*
}

\author{
Kim Pettersson ${ }^{\dagger}$ and Ole Sorensen ${ }^{\ddagger}$ \\ Copenhagen Business School, Department of Accounting and Auditing, \\ Solbjerg Plads 3, 2000 Frederiksberg, Denmark
}

\begin{abstract}
We demonstrate how the valuation models used in finance theory and the profitability and growth analysis taught in financial statement analysis are related. Traditional textbooks on finance and financial statement analysis are often very comprehensive, comprising a vast number of chapters. However, the learning cost associated to this seems to be that many students are unable to understand either the interrelations between the chapters in a financial statement analysis textbook, or the origins of financial information (i.e., financial statements) in applied finance. Thus, the underlying motivation of this teaching note is to highlight the purpose of profitability and growth analysis in financial statement analysis by incorporating the point of value relevance in applied finance. We hope this reduced presentation of valuation and profitability and growth analysis will help students to understand these interrelations. Finally, we offer students the necessary analytical flexibility to create their own coherent profitability and growth analyses.
\end{abstract}

Key words: Accounting, finance, profitability and growth analysis, valuation, value relevance.

JEL classification: A23, G17, M41

\footnotetext{
*We would like to thank Mostaq M. Hussain (editor), two anonymous reviewers, Jeppe G. Christoffersen and seminar participants at the Copenhagen Business School for helpful comments. All errors are our own.

${ }^{\dagger}$ Assistant Professor.

¥Associate Professor; corresponding author: email: os.acc@cbs.dk; tel.: +45-38152346; fax: $+45-38152321$
} 


\section{Introduction}

In this teaching note, we introduce a combined presentation of accounting-based valuation and of profitability and growth analysis. We relate elementary finance theory with undergraduate profitability and growth analysis by using only a minimum of high school level math. Students who study financial statement analysis do not fully understand the purpose of profitability and growth analysis from a valuation perspective. Similarly, students taking lessons in finance theory sometimes seem unaware of the origin and relevance of the financial information which enters valuation models. Many students think that valuation as well as profitability and growth analysis are complex topics. The vast number of chapters in textbooks for courses in finance theory and financial statement analysis may be the reason for the students' somehow fragmented understanding of the course materials. Finally, we show how students can create their own version of the well-known DuPont model.

We believe that the gap in many bright students' understanding is simply rooted in the fact that they do not know how the formulas are related. Broadly speaking, finance courses deal with the denominator of any net present valuation formulas whereas financial statement courses consider the numerator. That is, students should realize that financial statement analysis and finance theory are complements, not independent business economic disciplines. In our view, the separate teaching success in each course relies (to some extent) on the understanding of this message. Thus, our aim is to demonstrate (in a few pages) and motivate the core elements which connect finance theory (i.e., valuation) and financial statement analysis (i.e., profitability and growth analysis). Hopefully, this will trigger the students' desire to take courses in both finance theory and financial statement analysis.

The target audience of this teaching note consists of students and lecturers who are learning and teaching, respectively, financial statement analysis (at the intermediate or advanced levels) and/or finance theory (at the introductory or intermediate levels). First, we present some basic techniques of financial statement analysis and finance theory. Second, we integrate these two disciplines based on their interrelations. By doing it this way, we hope this teaching note will both help lectures facilitate the students' learning and help students apply financial statement analysis to finance theory, and vice versa.

In Sections 2 and 3, we explain the link between the residual income valuation model and profitability and growth analysis. Next, we emphasize the point of value relevance of accounting information in valuation models. In Section 5, we outline the mechanics underlying the creation of profitability ratios. Our objective is to offer the students the necessary tools (i.e., analytical flexibility) to create any profitability ratios and (as a result) growth analysis of analytical importance from a valuation perspective. We make a short comment on the importance of financial accounting for profitability and growth analysis as well as for valuation in Section 6. We conclude in the final section, and we refer connoisseurs to the appendices. 


\section{Equity valuation theory}

Consider the well-known dividend discount model (DDM) taught in all basic finance courses (e.g., Brealey et al., 2008; Copeland \& Weston, 1992; Hillier et al., 2011):

$$
V_{0}=\sum_{t=1}^{\infty} E_{0}\left[d_{t}\right] \times(1+r)^{-t}
$$

The value of equity $\left(V_{0}\right)$ is the present value of the expected $\left(E_{0}\right)$ future (net) dividend payments ${ }^{1}\left(d_{t}\right)$ where $r$ denotes the cost of capital ${ }^{2}$. Although theoretically correct, the dividend discount model is inappropriate in practice, as the value of equity is independent of current dividend payout decisions ${ }^{3}$. This is the reason why academia and practitioners turn to other valuation models which are not expressed in terms of dividend payments.

\subsection{Derivation of the residual income valuation model}

Let $C E_{t}$ and $C I_{t}$ denote the book values of (common) equity and comprehensive income (or clean surplus earnings) of the firm, respectively. The change in equity of the firm is equal to comprehensive income less (net) dividend payments:

$$
\partial C E_{t}=C E_{t}-C E_{t-1} \stackrel{(\text { def })}{=} C I_{t}-d_{t} \Leftrightarrow d_{t}=C I_{t}-C E_{t}+C E_{t-1}, t=1,2, \ldots
$$

Based on the clean surplus relation (CSR) in Equation (2), we are able to define dividend payments in period $t^{4}$. This is the Preinreich (1937) Theorem, stating that if CSR holds, the residual income and the cash flow valuation models result in exactly the same equity valuation. Thus, substituting Equation (2) into (1) yields

$$
V_{0}=\sum_{t=1}^{\infty} E_{0}\left[C I_{t}-C E_{t}+C E_{t-1}\right] \times(1+r)^{-t}
$$

Let $R I_{t}$ denote residual income (or residual earnings). $R I_{t}$ reflects the firm's ability to generate excess profit:

$$
R I_{t}=C I_{t}-r \times C E_{t-1}
$$

Substituting Equation (4) into (3) yields the residual income valuation model in infinite time (for more on this, see Ohlson, 1995)

\footnotetext{
${ }^{1}$ Net dividend payments $=$ dividend payments $-($ share repurchases + share issues $)$

2 The equity cost of capital (i.e., investors' required rate of return) is determined by, e.g., the capital asset pricing model (CAPM). For simplicity, we assume that the cost of capital is constant over time.

${ }^{3}$ This is due to the proposition of Miller \& Modigliani (1961): Dividend policy irrelevance, see Appendix A.

${ }^{4}$ To aid understanding, we ignore changes in equity resulting from changes not related to comprehensive income (i.e., transactions with the owners).
} 


$$
\begin{gathered}
V_{0}=C E_{0}+\sum_{t=1}^{\infty} E_{0}\left[R I_{t}\right] \times(1+r)^{-t} \\
\text { as } C E_{t} \times(1+r)^{-t} \longrightarrow 0 \text { for } t \longrightarrow \infty
\end{gathered}
$$

As forecasts of residual income to infinity are a practical problem, we have to truncate time ${ }^{5}$ :

$$
V_{0}=C E_{0}+\sum_{t=1}^{T} E_{0}\left[R I_{t}\right] \times(1+r)^{-t}+T V \times(1+r)^{-T} \text { where }
$$

$$
T V=E_{0}\left[R I_{T}\right] \times(1+g) \times(r-g)^{-1}=\text { terminal value and } g=\text { growth rate }
$$

Equation (5) is the first "principal" equation as it is the basis for the profitability and growth analysis in Section 3. Further, the residual income model has two main benefits. First, the residual income model anchors the value of equity $\left(V_{0}\right)$ based on financial statements (not dividend payments) as it links financial statements and equity valuation directly. Second, the term $R I_{t}$ signals the value added in period $t$. If $R I_{t} \geq 0\left(R I_{t} \leq 0\right)$, the firm does not destroy (create) shareholder value. Thus, the residual income model forces investors to focus on the determinants of expected residual income (i.e., the drivers of value creation).

\section{Profitability and growth analysis}

All students taking lessons in financial statement analysis are familiar with some version of the DuPont model (e.g., Penman, 2010; see also Lundholm \& Sloan, 2007; Petersen \& Plenborg, 2012), disentangling the overall key profitability ratio $R O E_{t}=C I_{t} / C E_{t-1}$ (return on equity) into the underlying value drivers, i.e., into the underlying profitability $\operatorname{ratios}^{6}$ :

$<<$ Insert DuPont model about here $>>$

Based on historical financial statements, the ratios in the DuPont model are used to analyse the ex post profitability of a firm: What drives the current return on equity $\left(R O E_{t}\right)$ ? With this knowledge in mind, investors begin to forecast the future by asking how future profitability will be different from the current profitability $\left(R O E_{t}\right)$.

\footnotetext{
${ }^{5}$ This version of the residual income valuation model is the well-known Gordon growth model in finite time, see Appendix B for a derivation of the terminal value $(T V)$.

${ }^{6}$ If minority interests or net financial assets appear on the reformulated balance sheet (we will however not go through the reformulation technology, as that is beyond the scope of this teaching note) then the formulas are slightly different.
} 
Now we demonstrate the integration of valuation with profitability and growth analysis in just a few simple steps. Again, consider the residual income expression entering the residual income model in Equation (5):

$$
R I_{t}=C I_{t}-r \times C E_{t-1}=\left(R O E_{t}-r\right) \times C E_{t-1}
$$

Equation (6) is the second "principal" equation, i.e., Equation (6) is the link to valuation. Students should note that the return on equity $\left(R O E_{t}\right)$ now enters into the residual income model in Equation (5). This is the important relation which links the residual income model (i.e., valuation) and the profitability ratios in the DuPont model. Equity value is driven by the profitability $\left(R O E_{t}-r\right)$ or, in this case, $R O E_{t}$ and growth in equity $\left(C E_{t-1}\right)^{7}$. So valuation requires understanding the drivers of profitability and growth, and the latter will be the subject of the next subsection.

\subsection{Growth analysis by means of total differentiation}

When one looks at any textbook in financial statement analysis, it's easy to see that growth analysis is merely some first order differences of the profitability ratios in the DuPont model. However, many students are not fully aware of the overall systematic in growth analysis. How do these formulas come into existence? In this subsection, we show that the growth in residual income $(R I)$ is based on the total differentiation of the DuPont model and the book value of equity.

Again, consider the residual income model in Equation (5). We are interested in the expected growth in residual income, cf. Equation (6). To estimate future residual income, i.e., the growth in residual income, investors must examine historical financial statements of the firm (and other information) to explain the present in order to project the future residual income of the firm. Total differentiation (with respect to time, see Appendix $\mathrm{C})^{8}$ of the residual income expression in Equation (6) yields the (ex post) growth in residual income ${ }^{9}$ :

$$
\begin{aligned}
\partial R I_{t} & =\partial\left(R O E_{t}-r\right) \times C E_{t-1}+\left(R O E_{t}-r\right) \times \partial C E_{t-1} \\
& =\underbrace{\partial R O E_{t} \times C E_{t-1}}_{(a)}+\underbrace{\left(R O E_{t}-r\right) \times \partial C E_{t-1}}_{(b)}
\end{aligned}
$$

The growth in residual income in Equation (7) is decomposed into the growth in profitability (a) and the growth in equity (b), i.e., the two main factors driving overall growth in residual income and, as a result, valuation. From a valuation

\footnotetext{
${ }^{7}$ To see this, for any given level of equity $\left(C E_{t-1}\right)$, an increase in profitability $\left(R O E_{t}-r\right)>$ 0 will increase shareholder value. Similar, for any given level of profitability $\left(R O E_{t}-r\right)>0$, an increase in equity $\left(C E_{t-1}\right)$ will increase shareholder value.

${ }^{8}$ Unlike partial derivatives, total derivatives do not require that the argument remain constant as time varies.

${ }^{9}$ Regarding the last equality sign, $\partial\left(R O E_{t}-r\right)=\partial R O E_{t}-\partial r=\partial R O E_{t}$ where $\partial r=0$ as $r$ is constant over time, cf. footnote 2 .
} 
perspective, we are interested in whether ex post profitability and growth will continue in the future or not. This is similar to asking whether comprehensive income is sustainable and forms a basis for growth or whether comprehensive income consists of one-time components which will not be repeated in the future (for more on this, see Section 4). Reconsidering Equation (5), this reflects our primary goal: To predict future residual income in order to estimate the value of equity.

We consider the two terms (a) and (b) in Equation (7) one at the time starting with (a):

$$
\begin{gathered}
\partial R O E_{t} \times C E_{t-1}=(\underbrace{\partial R N O A_{t}}_{(a)} \\
+\underbrace{\partial F L E V_{t} \times S P R E A D_{t}+F L E V_{t} \times \partial S P R E A D_{t}}_{(b)}) \times C E_{t-1}
\end{gathered}
$$

In Equation (8), the change in return on equity $\left(\partial R O E_{t}\right)$ consists of (a) the change in return on net operating assets $\left(\partial R N O A_{t}\right)$, i.e., the change in the operating activity of the firm, and (b) the change in financial leverage $\left(\partial F L E V_{t} \times S P R E A D_{t}+F L E V_{t} \times \partial S P R E A D_{t}\right)$, i.e., the change in the financing activity of the firm.

Before we move on, let's consider the definitions of return on net operating assets $\left(R N O A_{t}\right)$, financial leverage $\left(F L E V_{t}\right)$, and operating spread $\left(S P R E A D_{t}\right)$ :

$$
\begin{aligned}
& R N O A_{t}=\frac{O I_{t}}{N O A_{t-1}}=P M_{t} \times A T O_{t} \\
& O I_{t}=\text { operating income } \\
& N O A_{t-1}=\text { net operating assets } \\
& P M_{t}=\frac{O I_{t}}{\text { Sales }_{t}}=\text { profitmargin } \\
& A T O_{t}=\frac{\text { Sales }_{t}}{N O A_{t-1}}=\text { asset turnover ratio } \\
& F L E V_{t}=\frac{N F O_{t-1}}{C_{t-1}}, N F O_{t-1}=\text { net financial obligations } \\
& S P R E A D_{t}=R N O A_{t}-N B C_{t}, N B C_{t}=\frac{N F E_{t}}{N F O_{t-1}} \\
& =\text { net borrowing costs where } N F E_{t}=\text { net financial expenses }
\end{aligned}
$$

Now it's time to consider term (a) in Equation (8): 


$$
\partial R N O A_{t}=\partial P M_{t} \times A T O_{t}+P M_{t} \times \partial A T O_{t}
$$

With forecasting in mind, we are interested in components which have predictive value for the future. Thus, we split operating income $\left(O I_{t}\right)$ into recurring (or core) operating income $\left(O I_{t, \text { Core }}\right)$ and non-recurring (or non-core) operating income $\left(O I_{t, N o n-C o r e}\right)$ which yield the corresponding profit margins $P M_{t, \text { Core }}$ and $P M_{t, \text { Non-Core }}$, respectively:

$$
\begin{gathered}
P M_{t}=P M_{t, \text { Core }}+P M_{t, \text { Non-Core }} \text { where } \\
P M_{t, \text { Core }}=\frac{O I_{t, \text { Core }}}{\text { Sales }_{t}} \text {, and } P M_{t, \text { Non-Core }}=\frac{O I_{t, \text { Non-Core }}}{\text { Sales }_{t}}
\end{gathered}
$$

Using the definitions of profit margins, we are able to restate Equation (9) in growth terms:

$$
\begin{gathered}
\partial R N O A_{t}=\partial P M_{t, \text { Core }} \times A T O_{t}+P M_{t, \text { Core }} \times \partial A T O_{t} \\
+\partial P M_{t, \text { Non-Core }} \times A T O_{t}+P M_{t, N o n-C o r e} \times \partial A T O_{t}
\end{gathered}
$$

In Section 4, we elaborate on what we mean by value relevance from an accounting-based valuation perspective. So far, our aim is just to show how valuation, profitability and growth analysis are related to operating activities.

Next, we elaborate on term (b) in Equation (8), i.e., we turn our attention to the corresponding integration related to financial activities only:

$$
\begin{gathered}
\partial F L E V_{t}=\partial\left(\frac{1}{C E_{t-1}}\right) \times N F O_{t-1}+\frac{1}{C E_{t-1}} \times \partial N F O_{t-1} \\
\partial S P R E A D_{t}=\partial R N O A_{t}-\underbrace{\partial N B C_{t}}_{(a)}
\end{gathered}
$$

In Equation $(11)^{10}$, it is clear that any changes in financial leverage $\left(\partial F L E V_{t}\right)$ are driven by changes in net financial obligations $\left(\partial N F O_{t-1}\right)$ or the reciprocal of equity $\left(\partial\left(1 / C E_{t-1}\right)\right)$. However, to determine whether the change in financial leverage contributes to return on equity $\left(R O E_{t}\right)$ hinges on the sign of the matching change in operating spread $\left(\partial S P R E A D_{t}\right)$ cf. Equation (8).

With regards to term (a) in Equation (12), only recurring items have predictive value. This calls for a decomposition of the growth in net borrowing costs $\left(\partial N B C_{t}\right)$ into net borrowing costs from core items (i.e., sustainable financial items) $\left(N B C_{t, \text { Core }}\right)$ and net borrowing costs from non-core items (i.e., non-sustainable financial items) $\left(N B C_{t, \text { Non-Core }}\right)$ :

$$
\partial N B C_{t}=\partial N B C_{t, \text { Core }}+\partial N B C_{t, N o n-C o r e}
$$

\footnotetext{
${ }^{10}$ We rearrange the expression for financial leverange $F L E V_{t}=\frac{N F O_{t-1}}{C E_{t-1}}=\frac{1}{C E_{t-1}} \times$ $N F O_{t-1}$ before we differentiate the expression.
} 
Now we return to the change in residual income $\left(\partial R I_{t}\right)$ following a change in equity $\left(\partial C E_{t-1}\right)$, i.e., term (b) in Equation (7):

$$
\left(R O E_{t}-r\right) \times \partial C E_{t-1}=\left(R O E_{t}-r\right) \times[\underbrace{\partial\left(\frac{\text { Sales }_{t-1}}{A T O_{t-1}}\right)}_{(a)}-\partial N F O_{t-1}]
$$

Equation (13) follows by definition, as $C E_{t-1}=N O A_{t-1}-N F O_{t-1}{ }^{11}$ and $N O A_{t-1}=$ Sales $_{t-1} / A T O_{t-1}$. It is clear from Equation (13) that any change in equity $\left(\partial C E_{t-1}\right)$ results from changes in net operating assets $\left(\partial N O A_{t-1}=\right.$ $\partial\left(\right.$ Sales $\left.\left._{t-1} / A T O_{t-1}\right)\right)$ or net financial obligations $\left(\partial N F O_{t-1}\right)$. Finally, we consider the (a) in Equation (13):

$$
\partial\left(\frac{\text { Sales }_{t-1}}{A T O_{t-1}}\right)=\partial\left(\frac{1}{A T O_{t-1}}\right) \times \text { Sales }_{t-1}+\left(\frac{1}{A T O_{t-1}}\right) \times \partial \text { Sales }_{t-1}
$$

In Equation (14) ${ }^{12}$, changes in net operating assets are attributed to changes in the reciprocal of the asset turnover $\left(\partial\left(\frac{1}{A T O_{t-1}}\right)\right)$ or sales $\left(\partial\right.$ Sales $\left._{t-1}\right)$.

Consider Equations (10) and (13): sales enter into the essential profitability ratios $P M_{t}, A T O_{t}$ and $N O A_{t}={\text { Sales } t-1 / A T O_{t-1}}_{\text {which drive the changes in }}$ return on equity $\left(\partial R O E_{t}\right)$ and equity $\left(\partial C E_{t}\right)$ and (as a result) the residual income in Equation (6). This is the reason, among other things, why most textbooks in accounting-based valuation teach students to forecast sales first, i.e., put forward sales budgets, followed by forecasts of matching expenses to calculate the operating profit, etc. Thus, sales is the most important driver of equity value.

To summarize, we have derived the principal links between the residual income valuation model, profitability ratios in the DuPont model, and growth analysis. Somehow, many students who take lessons in financial statement analysis seem to ask the question: What is the purpose of studying profitability and growth analysis? Equations (5) and (6) give the answer. Are we done now? No, investors' attribute different degrees of relevance to the inputs into the financial statements in valuation models.

\section{Value relevance}

This section operationalizes (a modified version of) the residual income model in Equation (5), see the motivation below. In addition, we demonstrate the importance of value relevance when investors use accounting-based valuation models. Somehow, this seems not to be appreciated by students taking courses in, e.g., applied finance.

\footnotetext{
${ }^{11}$ This is a rearrangement of the familiar balance sheet equation (BSE).

${ }^{12}$ Again, we use the same technique and rearrange the expression for net operating assets $N O A_{t-1}=\frac{\text { Sales }_{t-1}}{A T O_{t-1}}=\frac{1}{A T O_{t-1}} \times$ Sales $_{t-1}$ before we differentiate the expression.
} 
In practice, investors apply a modified version of the residual income model in Equation (5). To estimate the value of equity $\left(V_{0}\right)$, investors estimate the value of net operating assets $\left(N O A_{t}\right)$ and (subsequently) subtract the book value of net financial obligations $\left(N F O_{0}\right)$. The reason (or assumption) is that financial liabilities and assets on the balance sheet reflect the market value (i.e., markto-market, which refers to the current market price). That is, the assumptions of complete and perfect markets only hold for net financial obligations. As a result, investors only have to forecast residual income from operating activities in order to estimate the value of equity (for more on this, see Appendix D). This may explain why these types of accounting-based valuation models (e.g., the discounted cash flow model) are so popular among investors (and others): They are both "lazy" and clever as financial assets or obligations are traded on markets with high trading volumes etc. (i.e., efficient markets).

\subsection{An example}

We consider a highly simplified example with two investors (A and B), who consider investing in a non-financial firm (e.g., manufacturing), to illustrate the importance of value relevance from an accounting-based valuation perspective. Thus, we ignore financing activities (as explained above), dividend payouts equal zero, and the cost of capital $(r)$ is $8 \%$ (i.e., we assume $r=r_{W A C C}$ where $r_{W A C C}$ is the weighted average cost of capital for operating activities, which is standard knowledge in both finance and financial statement analysis, see, e.g., Modigliani \& Miller, 1958, 1963).

Profitability and growth analysis shows the financial statement drivers of return on equity $\left(R O E_{t}\right)$ and growth in equity $\left(C E_{t}\right)$ which drive residual income $\left(R I_{t}\right)$ and (as a result) the value of equity $\left(V_{0}\right)$. The financial statement drivers generate both current and future rates of return on equity and book values of equity and (as a result) form the building blocks for forecasts of RI. In forming expectations about the future, the investor will start by asking how future profitability and growth will be different from the current. So a point of departure is the current comprehensive income or rates of return on equity. However, only permanent (i.e., recurring) income items have value relevance (or predictive value).

Consider the balance sheet and income statement of a firm. We assume imperfect markets (for some of the operational assets in the balance sheet). Thus, the income statement (i.e., the information) is also important from an accounting-based valuation perspective.

\begin{tabular}{|c|c|c|c|c|c|}
\hline \multicolumn{6}{|c|}{ Balance sheet (ultimo) in dollars } \\
\hline & $t=-1$ & $t=0$ & & $t=-1$ & $t=0$ \\
\hline NOA $_{t}$ & 100 & 103 & $C E_{t}$ & 100 & 103 \\
\hline
\end{tabular}




\begin{tabular}{|l|c|}
\hline \multicolumn{2}{|c|}{ Income statement $(t=0)$ in dollars } \\
\hline Sales & 150 \\
\hline Costs of goods sold & -100 \\
\hline Selling, general, and administrative expenses & -40 \\
\hline Gains from asset sales & 5 \\
\hline & \\
\hline$=O I_{t}(=$ operating income $)$ & 15 \\
\hline
\end{tabular}

Let superscript 'A' and 'B' denote the type of investor: investor (A) B does (not) suffer from functional fixation. That is, investor B näively extrapolates current growth rates in residual income into the future, whereas investor A does not.

First, consider investor B. It's easy to see that the current return on equity $\left(R O E_{0}=R N O A_{0}\right)$ is $15 \%$ and (as a result) the current residual income $\left(R I_{0}\right)$ is 7. As investor B suffers from functional fixation, (s)he expects that the current rate of return on equity $\left(R O E_{t}\right)$ of $15 \%$ and that the growth in equity $\left(\triangle C E_{0} / C E_{-1}=\triangle N O A_{0} / N O A_{-1}\right)$ of $3 \%$ will continue in the future (i.e., $\left.t=1,2, \ldots\right)$. In this case, the growth rate $(\mathrm{g})$ in residual income is also $3 \%$ in steady state ${ }^{13}$. Thus, the value of the firm $\left(V_{0}=V_{N O A_{0}}\right)$ is equal to that of a perpetuity with an infinite growth rate of $3 \%$, cf. Equation (5):

$$
\begin{gathered}
V_{0}^{B}=C E_{0}+\frac{R I_{1}}{r-g}=103+\frac{(1+0.03) \times 7}{0.08-0.03}=247 \text { as } R I_{1}=(1+g) \times R I_{0} \\
o r \\
V_{0}^{B}=C E_{0}+\frac{\left(R O E_{1}-r\right) \times C E_{0}}{r-g}=103+\frac{(0.15-0.08) \times 103}{0.08-0.03}=247
\end{gathered}
$$

Second, consider investor A. As investor A does not suffer from functional fixation, (s)he realizes that current operating income $\left(O I_{0}=C I_{0}\right)$ consists of permanent (or recurring) as well as non-permanent items of 10 and 5 dollars, respectively. As gains from sales of assets ${ }^{14}$ are not expected to continue in the future, investor A does not capitalize non-permanent gains or losses and (as a result) the permanent residual income is 2 :

$$
V_{0}^{A}=103+\frac{(1+0.03) \times 2}{0.08-0.03}=144
$$

To summarize, investor B (erroneously) attributes a higher equity value to the firm than investor $A$. This is the important point of value relevance. What this example implies is that only recurring (i.e., permanent) activities have predictive value in accounting-based valuation approaches.

\footnotetext{
${ }^{13}$ The steady state condition requires that the growth rate in residual income $\left(\frac{\triangle R I_{t}}{R I_{t-1}}=\right.$ $g_{t}=g$ for all $\left.t=1,2, \ldots\right)$ is constant over time. In a correct application of Gordon's growth model, steady state is a necessary condition.

${ }^{14}$ Sales of assets are not a part of the business model of a manufacturing firm.
} 


\section{The student's tool box}

In this section, we focus on the few necessary mathematical tools and fundamental accounting relations which will enable students to advance any hierarchical structure of profitability ratios of their own. Our objective is to teach the students how to design their "own" DuPont model, as we believe that in this way, they will achieve a better understanding of profitability and growth analysis, valuation, and financial accounting (for more on this, see Section 6).

\subsection{The clean surplus relation}

How do the income statements and balance sheets of any firm materialize into a hierarchical structure of profitability ratios? To answer this question, let's consider the following (reformulated and generic) income statement (IS) ${ }^{15}$ and balance sheet (BSE) of a firm:

\begin{tabular}{|c|c|}
\hline \multicolumn{2}{|c|}{ Income statement $(t=0)$} \\
\hline \multicolumn{2}{|l|}{$\begin{array}{l}\text { Sales }_{t} \\
\text { - Operating expenses }\left(O E_{t}\right)\end{array}$} \\
\hline \multicolumn{2}{|c|}{$=$ Operating income from sales $\left(O I_{t, \text { Core }}\right)$} \\
\hline \multicolumn{2}{|c|}{$\begin{array}{l}=\text { Operating income from non-core items }\left(O I_{t, N o n-C o r e}\right) \\
\ldots\end{array}$} \\
\hline \multicolumn{2}{|c|}{$=$ Net financial expenses $\left(N F E_{t}\right)$} \\
\hline \multicolumn{2}{|c|}{$=$ Comprehensive income $\left(C I_{t}\right)$} \\
\hline \multicolumn{2}{|c|}{ "Balance sheet equation (ultimot $=-1,0$ ) } \\
\hline$\ldots$ & Common equity $\left(C E_{t}\right)$ \\
\hline$=$ Operating assets $\left(O A_{t}\right)$ & $\ldots$ \\
\hline$\ldots$ & $=$ Operating liabilities $\left(O L_{t}\right)$ \\
\hline$=$ Financial assets $\left(F A_{t}\right)$ & $\ldots$ \\
\hline$=$ Total assets $\left(T A_{t}\right)$ & $=$ Financial liabilities $\left(F L_{t}\right)$ \\
\hline & $=$ Total liabilities $\left(T L_{t}\right)$ \\
\hline
\end{tabular}

The first key (K1) to the successful integration of income statements and balance sheets is the clean surplus relation (CSR) (in Equation (2)):

$$
C E_{t}-C E_{t-1} \stackrel{(C S R)}{=} C I_{t}-d_{t}
$$

As payment for supplying capital (i.e., equity), investors receive the surplus after the firm has fulfilled its obligations (e.g., creditors, banks, etc.): The change in equity $\left(C E_{t}-C E_{t-1}\right)$, i.e., dividend payments $\left(d_{t}\right)$ and postponed dividend payments $\left(C I_{t}-d_{t}\right)$. As absolute levels of earnings $\left(C I_{t}\right)$ are poor measures of the value added ${ }^{16}$, we express the CSR in percentage,

\footnotetext{
${ }^{15}$ To simplify, comprehensive income $=$ net income.

${ }^{16}$ For example, a comprehensive income of one million sounds impressive. However, if the risk-free interest rate is $20 \%$ and the book value of equity is 10 million, it is better to invest in the risk-free asset and do nothing. Thus, we remove scale effects.
} 


$$
\frac{d_{t}+C E_{t}-C E_{t-1}}{C E_{t-1}}=\frac{C I_{t}}{C E_{t-1}} \stackrel{(\text { def })}{=} R O E_{t}
$$

The second key (K2) to developing a hierarchical structure of profitability ratios is utilizing the linear structure in the income statement (IS):

$$
\begin{gathered}
R O E_{t}=\frac{C I_{t}}{C E_{t-1}} \stackrel{(I S)}{=} \frac{O I_{t, \text { Core }}+O I_{t, \text { Non-Core }}-N F E_{t}}{C E_{t-1}} \\
=\underbrace{\frac{O I_{t, \text { Core }}}{C E_{t-1}}}_{(a)}+\underbrace{\frac{O I_{t, N o n-C o r e}}{C E_{t-1}}}_{(b)}-\underbrace{\frac{N F E_{t}}{C E_{t-1}}}_{(c)} \\
=\frac{\text { Sales }_{t}-O E_{t}}{C E_{t-1}}+\frac{O I_{t, N o n-C o r e}}{C E_{t-1}}-\frac{N F E_{t}}{C E_{t-1}}=\ldots
\end{gathered}
$$

It is easy to see how one can exploit the linear structure in the income statement (IS) to derive more and more profitability ratios (or fractions) in terms of equity $\left(C E_{t-1}\right)$. The idea is that one can choose any combination of terms (a)(c) in Equation (16) as a profitability ratio. E.g., one could define the combinations i) operating income over equity $O I C E_{t}=\left(O I_{t, C o r e}+O I_{t, \text { Non-Core }}\right) / C E_{t-1}=$ $O I_{t, \text { Core }} / C E_{t-1}+O I_{t, N o n-C o r e} / C E_{t-1}$ and net financial expenses over equity $N F E C E_{t}=$ $N F E_{t} / C E_{t-1}$, ii) operating income from sales over equity $O I C E_{t, \text { Core }}=O I_{t, C o r e} / C E_{t-1}$, operating income from non-sales over equity $O I C E_{t, N o n-C o r e}=O I_{t, N o n-C o r e} / C E_{t-1}$, and net financial expenses over equity $N F E C E_{t}=N F E_{t} / C E_{t-1}$, or iii) any other. Further, one can split the term (a) into the underlying profitability ratios Salest $/ C E_{t-1}$ and $O E_{t, \text { Sales }} / C E_{t-1}$ etc. We hope (by now) that students are able to get a first glimpse of how the mechanics underlying the creation of any hierarchical structure of profitability ratios work: Just use your imagination.

\subsection{Fractions}

The third key (K3) to the engineering of a more varied hierarchical structure of profitability ratios is simple fractions, as taught in any high school:

$$
\begin{gathered}
\frac{x}{y}=\frac{x \times a}{y \times a}=\frac{x}{a} \times \frac{a}{y} \\
\frac{x}{y}=\frac{x / a}{y / a}=\frac{x}{a} \times \frac{1}{(y / a)} \\
\frac{1}{(x / a)}=\frac{a}{x}
\end{gathered}
$$

In combination with the fractions in Equations (17)-(19), the fourth key (K4) to designing a hierarchical structure of profitability ratios is using the linear nature of the balance sheet equation (BSE):

$$
T A_{t}=C E_{t}+T L_{t} \Leftrightarrow O A_{t}+F A_{t}=C E_{t}+O L_{t}+F L_{t} \Leftrightarrow
$$




$$
O A_{t}+F A_{t}-O L_{t}-F L_{t}=C E_{t} \Leftrightarrow \underbrace{N O A_{t}}_{=O A_{t}-O L_{t}}-\underbrace{N F O_{t}}_{=F L_{t}-F A_{t}}=C E_{t} \Leftrightarrow \ldots
$$

where

$$
\begin{gathered}
T A_{t}\left(T L_{t}\right)=\text { Total Assets (Liabilities) } \\
O A_{t}\left(O L_{t}\right)=\text { Operating Assets (Liabilities) } \\
F A_{t}\left(F L_{t}\right)=\text { Financial Assets (Liabilities) }
\end{gathered}
$$

\section{$N O A_{t}\left(N F O_{t}\right)=$ Net Operating Assets (Financial Obligations)}

To see how one can create any hierarchical structure of profitability ratios, we give an example of a variant of the DuPont model, where $N O A_{t-1}=$ $N O A_{t-1, \text { Core }}+N O A_{t-1, N o n-C o r e}$ as not all operating assets generate sales ${ }^{17}$. Thus, for example, our objective is to find a "cleaner" measure of return on net operating assets from sales $\left(R N O A_{t, \text { Core }}\right)$ other than the one (i.e. $\left.R N O A_{t}\right)$ in the DuPont model, which does not make this distinction. Consider Equation (16):

$$
\begin{aligned}
& R O E_{t}=\frac{C I_{t}}{C E_{t-1}} \stackrel{(I S)}{=} \frac{O I_{t}-N F E_{t}}{C E_{t-1}}=\frac{O I_{t}}{C E_{t-1}}-\frac{N F E_{t}}{C E_{t-1}} \stackrel{(17)}{=} \\
& \frac{O I_{t}}{C E_{t-1}}-\underbrace{\frac{N F E_{t}}{N F O_{t-1}}}_{=N B C_{t}} \times \underbrace{\frac{N F O_{t-1}}{C E_{t-1}}}_{=F L E V_{t}} \stackrel{(I S)}{=} \frac{O I_{t, \text { Core }}+O I_{t, N o n-C o r e}}{C E_{t-1}} \\
& -F L E V_{t} \times N B C_{t}=\frac{O I_{t, \text { Core }}}{C E_{t-1}}+\frac{O I_{t, N o n-C o r e}}{C E_{t-1}}-F L E V_{t} \times N B C_{t} \\
& \stackrel{(18)}{=} \underbrace{\frac{O I_{t, \text { Core }}}{N O A_{t-1, \text { Core }}}}_{=R N O A_{t, \text { Core }}} \times \frac{1}{C E_{t-1} / N O A_{t-1, \text { Core }}}+\underbrace{\frac{O I_{t, \text { Non-Core }}}{N O A_{t-1, \text { Non-Core }}}}_{=R N O A_{t, \text { Non-Core }}} \\
& \times \frac{1}{C E_{t-1} / N O A_{t-1, \text { Non-Core }}}-F L E V_{t} \times N B C_{t} \stackrel{(19)}{=} R N O A_{t, \text { Core }} \times
\end{aligned}
$$

${ }^{17}$ Although (investments in) associated companies, where the ownership concentration is $(<20 \%) 20 \%-50 \%$, generate profit, it's not related to sales from customers. 


$$
\begin{aligned}
& \frac{N O A_{t-1, \text { Core }}}{C E_{t-1}}+R N O A_{t, N o n-C o r e} \times \frac{N O A_{t-1, N o n-C o r e}}{C E_{t-1}}-F L E V_{t} \times N B C_{t} \\
& \stackrel{(B S E)}{=} R N O A_{t, \text { Core }} \times \frac{C E_{t-1}+N F O_{t-1}-N O A_{t-1, N o n-C o r e}}{C E_{t-1}} \\
& +R N O A_{t, N o n-C o r e} \times \frac{C E_{t-1}+N F O_{t-1}-N O A_{t-1, \text { Core }}}{C E_{t-1}}-F L E V_{t} \times N B C_{t} \\
& =R N O A_{t, \text { Core }} \times(1+\underbrace{\frac{N F O_{t-1}}{C E_{t-1}}}_{=F L E V_{t}}-\frac{N O A_{t-1, N o n-C o r e}}{C E_{t-1}})+R N O A_{t, N o n-C o r e} \\
& \times(1+\underbrace{\frac{N F O_{t-1}}{C E_{t-1}}}_{F L E V_{t}}-\frac{N O A_{t-1, \text { Core }}}{C E_{t-1}})-F L E V_{t} \times N B C_{t}
\end{aligned}
$$

Thus,

$$
\begin{gathered}
R O E_{t}=R N O A_{t, \text { Core }}+R N O A_{t, N o n-C o r e}+F L E V_{t} \\
\times\left(R N O A_{t, \text { Core }}+R N O A_{t, N o n-C o r e}-N B C_{t}\right)-R N O A_{t, \text { Core }} \\
\times \frac{N O A_{t-1, N o n-C o r e}}{C E_{t-1}}-R N O A_{t, N o n-C o r e} \times \frac{N O A_{t-1, \text { Core }}}{C E_{t-1}}
\end{gathered}
$$

As we demonstrated above, students can develop and design their "own" DuPont model. They are no longer dependent on predefined formulas in textbooks. This kind of analytical flexibility allows them to adjust profitability analyses to their individual needs, for specific information about profitability (e.g., in different industries): No one size fits all.

When having developed the desired hierarchical structure of profitability ratios, the fifth key (K5) is total differentiation (see Appendix C), as in subsection 3.1. Total differentiation of the hierarchical structure of profitability ratios converts it into a coherent growth analysis which originates from the dividend model, cf. Equation (1). That is, we hope (by now) that students are able to see how valuation is integrated with a profitability and growth analysis. 


\section{A short comment on the importance of finan- cial accounting}

Why is financial accounting important from not only a financial statement analysis point of view, but also from a valuation perspective?

One answer is inherent in the objective of financial accounting: Recognition and measurement of the business activities of a firm. In an ideal world, recognition and measurement of financial statements should reflect a true and fair view. However, in a world of incomplete or imperfect markets, some amount of human judgment is necessary. Thus, human judgment appears in the financial statements. As a result, the recognition and measurement of assets and liabilities is ambiguous. For this reason, accounting phenomena, such as earnings management, conservatism, smoothness, etc., may result in biased financial statements. This will impair the lens through which we look at profitability and growth and (as a result) equity value.

So, although all valuation models are mathematically correct, it's likely that a (real world) estimate of the value of equity is not correct if the input (i.e., financial information) which is used in the valuation technology is biased. Thus, our point is that unbiased financial information is a necessary condition for correct estimates of the equity value of a firm.

\section{Concluding remarks}

To emphasize the importance of value relevance, students learning, e.g., applied finance, should realize that the accuracy of valuation models reflects the "quality" of the underlying accounting numbers (i.e., financial information). Thus, we hope that the integration of elementary concepts in both financial statement analysis and finance theory in this teaching note will result in a better understanding and awareness of both disciplines on the part of the students.

\section{References}

[1] Brealey, R. A., Meyers, S. C., Allen, F. (2008). Principles of Corporate Finance. McGraw-Hill.

[2] Copeland, T. E., Weston, J. F. (1992). Financial Theory and Corporate Policy. Addison-Wesley.

[3] Gordon, M. J. (1959). Dividends, Earnings and Stock Prices. The Review of Economics and Statistics 41 (2): 99-105.

[4] Hillier, D., Clacher, I., Ross, S., Westerfield, R., Jordan, B. (2011). Fundamentals of Corporate Finance. McGraw-Hill.

[5] Lundholm, R., Sloan, R. (2007). Equity Valuation and Analysis. McGrawHill. 
[6] Miller, M. H., Modigliani, F. (1958). The cost of capital, corporation finance and the theory of investment. The American Economic Review 48 (3): $261-297$.

[7] Miller, M. H., Modigliani, F. (1961). Dividend policy, growth, and the valuation of shares. The Journal of Business 34 (4): 411-433.

[8] Miller, M. H., Modigliani, F. (1963). Corporate income taxes and the cost of capital: A correction. The American Economic Review 53 (3): 433-443.

[9] Ohlson, J. A. (1995). Earnings, book values, and dividends in equity valuation. Contemporary Accounting Research 11 (2): 661-687.

[10] Penman, S. H. (2010). Financial Statement Analysis and Security Valuation. McGraw-Hill.

[11] Petersen, C. V., Plenborg, T. S. (2012). Financial Statement Analysis - Valuation, Credit Analysis, Executive Compensation. Pearson.

[12] Preinreich, G. (1937). Valuation and Amortization. The Accounting Review 12: $209-226$.

\section{Appendix A: Dividend policy irrelevance}

Miller \& Modigliani (1961) show that the value of equity is independent of current dividend decisions if (A1) capital markets are perfect, (A2) investors are rational, and (A3) perfect certainty applies.

According to the fundamental principle of valuation (Miller \& Modigliani, 1961: 412):

The price of each share must be such that the rate of return (dividends plus capital gains per dollar invested) on every share will be the same throughout the market over any given interval of time.

That is,

$$
\begin{gathered}
p_{j t} \stackrel{(A 1, A 2)}{=} \frac{1}{1+r_{t}} \times[\text { div }_{j t}+\overbrace{p_{j t+1}}^{(A 3)}] \text { for each } j \text { and all } t \\
\text { where } \\
p_{j t}=\text { price of a share in firm } j \text { at the beginning of period } t \\
\text { div }_{j t}=\text { dividends per share paid in firm } j \text { during period } t \\
\rho_{j t}=\rho_{t}=\text { discounte rate for all } j \text { in period } t
\end{gathered}
$$


The fundamental principle of valuation in Equation (20) should be basic knowledge for all students taking any course in the theory of finance.

However, some students seem unaware of the link between the capital market and accounting numbers. That is, how are valuation models (and thereby accounting numbers) related to the share price of firm $j$ ? Let $n_{j t+1}$ and $m_{j t+1}$ denote the numbers of shares at the beginning of period $t+1$ and the numbers of new shares (if any) sold during period $t$, respectively. Thus,

(D1) $n_{j t+1}=n_{j t}+m_{j t+1}=$ number of shares at the end of period $t+1$

$(D 2) \tilde{V}_{j t}=n_{j t} \times p_{j t}=$ enterprise value of firm $j$ at the beginning of period $t$

$\left(\right.$ D3) $d_{j t}=n_{j t} \times$ div $_{j t}=$ dividend payments during period t in firm $j$

Let's restate the fundamental principle of valuation in Equation (20), but now in terms of the enterprise value of firm $j$ :

$$
\begin{gathered}
p_{j t}=\frac{1}{1+\rho_{t}} \times\left[d i v_{j t}+p_{j t+1}\right] \stackrel{(D 2)}{\Leftrightarrow} \frac{\tilde{V}_{j t}}{n_{j t}}=\frac{1}{1+\rho_{t}} \times\left[d i v_{j t}+p_{j t+1}\right] \stackrel{(D 3)}{\Leftrightarrow} \\
\tilde{V}_{j t}=\frac{1}{1+\rho_{t}} \times\left[n_{j t} \times \frac{d_{j t}}{n_{j t}}+n_{j t} \times p_{j t+1}\right] \stackrel{(D 1)}{\Leftrightarrow} \\
\tilde{V}_{j t}=\frac{1}{1+\rho_{t}} \times\left[d_{j t}+n_{j t+1} \times p_{j t+1}-m_{j t+1} \times p_{j t+1}\right] \stackrel{\left(D^{D 2}\right)}{\Leftrightarrow} \\
\tilde{V}_{j t}=\frac{1}{1+\rho_{t}} \times[\underbrace{d_{j t}}_{(i)}+\underbrace{\tilde{V}_{j t+1}-m_{j t+1} \times p_{j t+1}}_{(i i)}]
\end{gathered}
$$

(i) It's clear from Equation (21) that current dividend payments $\left(d_{j t}\right)$ directly affect the enterprise value of firm $j\left(\tilde{V}_{j t}\right)$. (ii) As the new ex dividend enterprise value $\left(\tilde{V}_{j t+1}\right)$ is independent of past dividend payments, $d_{j t}$ has no effect on the enterprise value of firm $j\left(\tilde{V}_{j t}\right)$ in period $t$. (iii) $d_{j t}$ has an indirect influence on $\tilde{V}_{j t}$ through the term $-m_{j t+1} \times p_{j t+1} \cdot m_{j t+1} \times p_{j t+1}$ is the value of new shares sold to outside investors during period $t$. In any period, high (low) levels of dividend payments will result in equally high (low) demand for capital from outside investors to maintain any given level of equity $\left(C E_{j t}\right)$. Thus, we are able to calculate the required amount of capital from outside investors:

$$
m_{j t+1} \times p_{j t+1}=C E_{j t}-\left[C I_{j t}-d_{j t}\right]
$$


where $C I_{j t}=$ comprehensive income

The dividend policy problem is that dividend policy decisions affect the enterprise value or share price in two conflicting ways: (i) and (iii), which exactly offset one another. Substituting Equation (22) into (21) results in the proposition of Miller \& Modigliani (1961), the irrelevance of dividend policy as dividend payments $\left(d_{j t}\right)$ cancel out:

$$
\begin{aligned}
\tilde{V}_{j t}= & \frac{1}{1+\rho_{t}} \times\left[d_{j t}+\tilde{V}_{j t+1}-m_{j t+1} \times p_{j t+1}\right] \stackrel{(22)}{=} \frac{1}{1+\rho_{t}} \times\left[d_{j t}+\tilde{V}_{j t+1}\right. \\
& \left.-\left(C E_{j t}-C I_{j t}+d_{j t}\right)\right]=\frac{1}{1+\rho_{t}} \times\left[C I_{j t}-C E_{j t}+\tilde{V}_{j t+1}\right]
\end{aligned}
$$

By now, students should realize that only accounting numbers, not dividend payments, appear in Equation (23). That is, enterprise values or share prices are determined solely by real considerations: In this case, the firm $j$ 's comprehensive income $\left(C I_{j t}\right)$ and equity policy $\left(C E_{j t}\right)$. In our view, this emphasizes the importance of financial accounting in financial statement analysis and, as a result, in relation to the theory of finance, as financial accounting is directly linked to $C I_{j t}$.

\section{Appendix B: Gordon's growth model}

The Gordon (1959) growth model includes a constant growth rate $(g)$ in the well-known dividend discount model in Equation (1).

In infinite time valuation models, it is a practical problem that investors (in theory) should forecast dividend payments, residual income, etc., to infinity. The inclusion of a constant growth rate $(g)$ allows us to restate the valuation model (i.e., a compounded valuation model) by breaking it down into two independent terms (a) and (b):

$$
V_{0}=C E_{0}+\underbrace{\sum_{t=1}^{T} E_{0}\left[R I_{t}\right] \times(1+r)^{-t}}_{(a)}+\underbrace{T V \times(1+r)^{-T}}_{(b)}
$$

The practical advantage is that the previously infinite time valuation model is now manageable. Investors can restrict themselves to residual income forecasts up to and including period $T$, cf. (a). As from period $T+1$, cf. (b), investors only have to determine the long run residual income growth rate $(g)$ in the term $T V$.

Let's calculate the expression for the terminal value $(T V)$ where $\hat{t} \geq T$ : 


$$
\begin{gathered}
T V=\sum_{\hat{t}=1}^{\infty} E_{0}\left[R I_{T}\right] \times(1+g)^{\hat{t}} \times(1+r)^{-\hat{t}}=\sum_{\hat{t}=1}^{\infty} E_{0}\left[R I_{T}\right] \times \frac{(1+g)^{\hat{t}}}{(1+r)^{\hat{t}}} \\
=\sum_{\hat{t}=1}^{\infty} E_{0}\left[R I_{T}\right] \times\left[\frac{1+g}{1+r}\right]^{\hat{t}}=\sum_{\hat{t}=1}^{\infty} E_{0}\left[R I_{T}\right] \times \delta^{\hat{t}} \text { where } \delta=\left[\frac{1+g}{1+r}\right]<1 \\
\text { or } \\
T V=E_{0}\left[R I_{T}\right] \times\left[\delta+\delta^{2}+\ldots\right]
\end{gathered}
$$

Next, multiply by $\delta$ on both sides of Equation (24):

$$
\delta \times T V=E_{0}\left[R I_{T}\right] \times \delta \times\left[\delta+\delta^{2}+\ldots\right]=E_{0}\left[R I_{T}\right] \times\left[\delta^{2}+\delta^{3}+\ldots\right]
$$

Finally, apply Bellman's equation to the infinite geometric series by subtracting Equation (25) from Equation (24):

$$
\begin{gathered}
T V-\delta \times T V=E_{0}\left[R I_{T}\right] \times\left[\delta+\delta^{2}+\ldots\right]-E_{0}\left[R I_{T}\right] \times\left[\delta^{2}+\delta^{3}+\ldots\right] \\
=E_{0}\left[R I_{T}\right] \times\left[\delta-\delta^{\hat{T}}\right]=E_{0}\left[R I_{T}\right] \times \delta \text { for } \hat{T} \longrightarrow \infty
\end{gathered}
$$

Solve for the terminal value $(T V)$,

$$
\begin{gathered}
T V=\frac{E_{0}\left[R I_{T}\right] \times \delta}{1-\delta}=\frac{E_{0}\left[R I_{T}\right] \times\left[\frac{1+g}{1+r}\right]}{1-\left[\frac{1+g}{1+r}\right]}=\frac{E_{0}\left[R I_{T}\right] \times\left[\frac{1+g}{1+r}\right]}{1-\left[\frac{1+g}{1+r}\right]} \times \frac{(1+r)}{(1+r)} \\
=\frac{E_{0}\left[R I_{T}\right] \times(1+g)}{(1+r)-(1+g)}=\frac{E_{0}\left[R I_{T}\right] \times(1+g)}{r-g} \\
\text { or } \\
T V=\frac{E_{0}\left[R I_{T+1}\right]}{r-g} \text { where } R I_{T+1}=R I_{T} \times(1+g)
\end{gathered}
$$

\section{Appendix C: Selected differentiation rules}

$$
\begin{gathered}
(f \pm g)(x) \Rightarrow f^{\prime} \pm g^{\prime} \text { or } \partial f \pm \partial g \\
(f \times g)(x) \Rightarrow f^{\prime} \times g+f \times g^{\prime} \text { or } \partial f \times g+f \times \partial g
\end{gathered}
$$




\section{Appendix D: Modified residual income model}

The motivation for a modification of the residual income model in Equation (5) is the assumption of complete and perfect markets. Let's consider the value of equity according to Equation (5):

$$
\begin{gathered}
V_{0}=C E_{0}+\sum_{t=1}^{T} E_{0}\left[R I_{t}\right] \times(1+r)^{-t}+T V \times(1+r)^{-T} \text { where } \\
T V=E_{0}\left[R I_{T}\right] \times(1+g) \times(r-g)^{-1}
\end{gathered}
$$

As $N O A_{t}-N F O_{t} \stackrel{(B S E)}{=} C E_{t}$ and $\left(C I_{t} \stackrel{(I S)}{=} O I_{t}-N F E_{t}\right)$, we are able to separate the residual income term in Equation (26):

$$
\begin{gathered}
R I_{t} \stackrel{(\text { def })}{=} C I_{t}-r \times C E_{t-1}=O I_{t}-N F E_{t}-r \times\left(N O A_{t-1}-N F O_{t-1}\right)= \\
(\underbrace{\left(O I_{t}-r \times N O A_{t-1}\right.}_{=R I_{t}^{N O A}})-\underbrace{\left(N F E_{t}-r \times N F O_{t-1}\right)}_{=R I_{t}^{N F O}} \text { where } \\
R I_{t}^{N O A}=\text { Residualincome from net operating assets and } \\
\text { and } \\
R I_{t}^{N F O}=\text { Residualincome from net financial obligations }
\end{gathered}
$$

Substituting Equations (27) and (BSE) into (26) yields

$$
\begin{gathered}
V_{0}=N O A_{0}+\sum_{t=1}^{T} E_{0}\left[R I_{t}^{N O A}\right] \times(1+r)^{-t}+T V^{N O A} \times(1+r)^{-T}- \\
\underbrace{\left(N F O_{0}+\sum_{t=1}^{T} E_{0}\left[R I_{t}^{N F O}\right] \times(1+r)^{-t}+T V^{N F O} \times(1+r)^{-T}\right)}_{(a)} \\
\text { where } T V^{N O A}=E_{0}\left[R I_{T}^{N O A}\right] \times(1+g) \times(r-g)^{-1} \\
T V^{N F O}=E_{0}\left[R I_{T}^{N F O}\right] \times(1+g) \times(r-g)^{-1}
\end{gathered}
$$


If the assumption of complete and perfect markets holds, term (a) in Equation (28) equals zero:

$$
\begin{gathered}
V_{0}=V_{0}^{N O A}-N F O_{0}= \\
N O A_{0}+\sum_{t=1}^{T} E_{0}\left[R I_{t}^{N O A}\right] \times(1+r)^{-t}+T V^{N O A} \times(1+r)^{-T}-N F O_{0} \\
o r \\
V_{0}=C E_{0}+\sum_{t=1}^{T} E_{0}\left[R I_{t}^{N O A}\right] \times(1+r)^{-t}+T V^{N O A} \times(1+r)^{-T}
\end{gathered}
$$

As a final remark (or curiosity), all accounting-based valuation models which estimate the value from net operating assets and (subsequently) subtract the book value of net financial obligations, rest on the assumption of perfect and complete markets. 


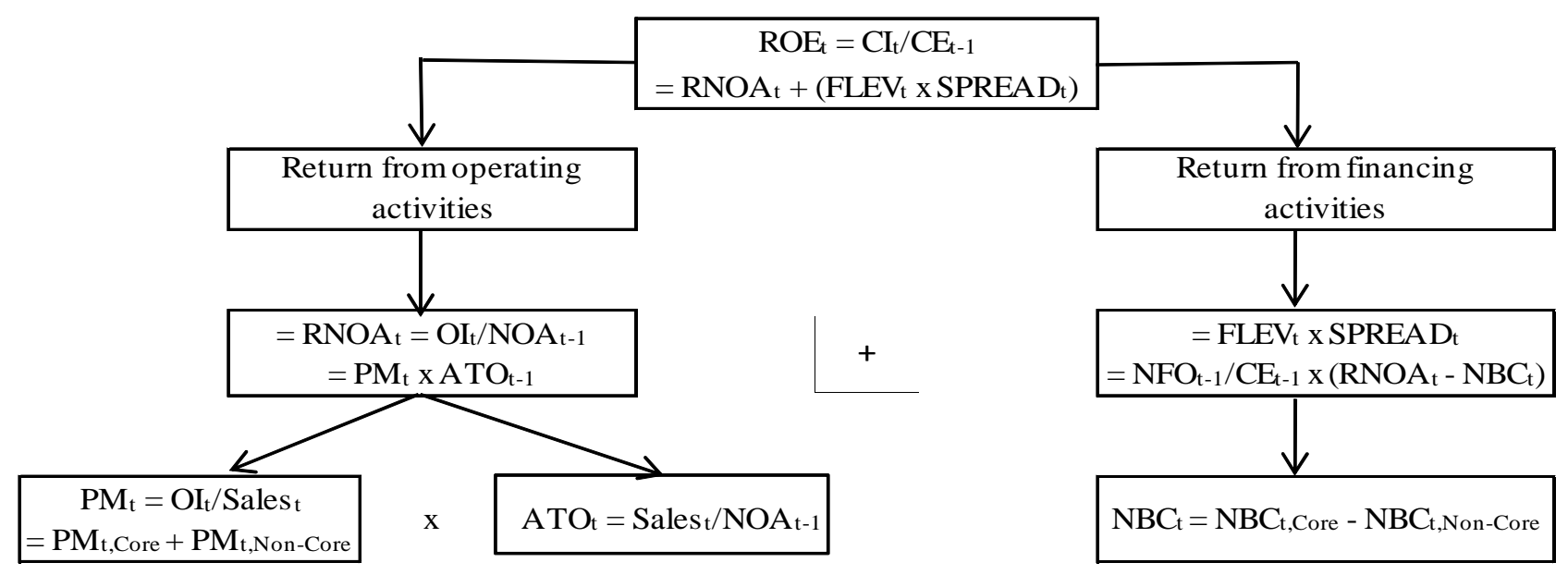

